\title{
GRANULOCYTIC SARCOMA IN BENIGN HYPERPLASIA OF PROSTATE: A CASE REPORT
}

Anitha S1, Prasad K. R. K², Sai Vittal³, Ravi Kumar M⿻

HOW TO CITE THIS ARTICLE:

Anitha S, Prasad K. R. K, Sai Vittal, Ravi Kumar M. “Granulocytic Sarcoma in Benign Hyperplasia of Prostate: A Case Report". Journal of Evolution of Medical and Dental Sciences 2015; Vol. 4, Issue 67, August 20;

Page: 11769-11772, DOI: 10.14260/jemds/2015/1696

ABSTRACT: Granulocytic sarcoma is a leukemic deposit in extra medullary sites. Such infiltrate may originate often from acute myeloid or acute lymphatic leukemia and rarely a chronic lymphocytic leukemia. Granulocytic sarcoma can be associated with or precede or occur after treatment of leukemia. Granulocytic sarcoma of chronic myeloid leukemia origin is very rare in prostate. Association of granulocytic sarcoma with benign hyperplasia of prostate is not reported in literature. Granulocytic sarcoma of chronic myeloid leukemia origin in prostate of 55 years old male associated with benign hyperplasia prostate is presented for its rarity.

KEYWORDS: Granulocytic sarcoma prostate, Granulocytic sarcoma with benign hyperplasia of prostate, Granulocytic sarcoma of chronic myeloid leukemia.

INTRODUCTION: Leukemia is a hematologic malignancy with systemic manifestations and rarely presents as a focal parenchymal infiltration called as chloroma ${ }^{1,2}$ or Granulocytic sarcoma. ${ }^{3}$ Primary lesions that result in granulocytic sarcoma are acute myeloid leukemia(AML) acute lymphoblastic leukemia(ALL), chronic lymphocytic leukemia(CLL), and myelodysplastic syndrome(MDS) and rarely in chronic myeloid leukemia(CML). ${ }^{4}$ The noted sites of granulocytic sarcomas are skin, lymphnodes, and gastrointestinal tract, testes, soft tissues, and central nervous system, bones, mediastinum, lung, epidura, uterus, ovaries, eye and rarely prostate..$^{1-12}$

Chronic myeloid leukemia resulting in chronic granulocytic sarcoma of prostate is very rare ${ }^{9-12}$ and more so association with benign hyperplasia of prostate is not reported in the literature so far. It is also important that such an extra medullary deposit can be a source of relapse in leukemia.

CASE REPORT: A 55 years old male patient presented to surgical clinic with complaints of decreased urine output, burning micturition and dribbling of urine since 15 days. General and systemic examinations were unremarkable. Routine laboratory investigations showed anemia with hemoglobin at $10.9 \mathrm{gm} \%$, WBC count of $5.6 \times 10^{3} / \mu \mathrm{L}$ with all mature white cells and platelet count at $2.3 \times 10^{3} / \mu \mathrm{L}$. Renal and liver function tests were within normal limits. Sonography of abdomen and pelvis revealed enlarged prostate measuring $5.3 \times 4.4 \times 4.3 \mathrm{~cm}$ with normal echotexture, prostate specific antigen (PSA) level was $0.760 \mathrm{ng} / \mathrm{ml}$. With a provisional diagnosis of grade III benign prostatic hyperplasia, a transurethral resection of prostate (TURP) was done and the tissue was subjected to routine histopathological examination.

Resected prostate bits were grey white soft measuring 20cc volume and grossly unremarkable. Multiple H \& E stained serial sections showed glandular and stromal hyperplasia of prostate (Fig. 1).The glands were lined by benign columnar epithelium and stroma showed smooth muscle hyperplasia along with focal nodular infiltrates (Fig. 2) consisting of hemopoietic cells including polymorphs, myelocytes, metamyelocytes and occasional promyelocytes (Fig. 3). Scant 
mature lymphocytic infiltrates in the stroma was also noted. Based on these histological features a diagnosis of granulocytic sarcoma of the prostate associated with benign adenomyomatous hyperplasia and chronic prostatitis was considered. A detailed enquiry into the past history revealed chemotherapy treatment for chronic myeloid leukemia 3yrs ago which the patient did not disclose at the time of admission due to fear of cancellation of surgical treatment.

DISCUSSION: Granulocytic sarcoma is an extra medullary accumulation of leukemic cells that occur in cases of acute myeloid leukemia, myelodysplastic syndrome, acute lymphoblastic leukemia, chronic lymphocytic leukemia and rarely in chronic myeloid leukemia. ${ }^{1-4,11,12}$ The noted sites of granulocytic sarcomas are skin, lymph nodes, GIT, testis. CNS, soft tissues and bones.6,8 These deposits were called as chloromas ${ }^{2}$ since they have green color due to presence of myeloperoxidase and fade away on exposure to light. Granulocytic sarcoma occurs mostly in established leukemia and presents uncommonly as an isolated neoplasm.6,10 Leukemic infiltration of prostate is often acute myeloid leukemia9,10 or lymphocytic leukemia with the latter often misdiagnosed as non-hodgkin's lymphoma.Granulocytic sarcoma of prostate is uncommon and those reported are with mean age of 67 years. ${ }^{10,11}$

Granulocytic sarcoma in prostate due to chronic myeloid leukemia in association with benign hyperplasia of prostate is not reported so far, ${ }^{9}$ Immunohistochemistry with anti MPO antibodies,CD68, CD43, and CD20,CD33 and CD117 can help in identification of granulocytic sarcoma ${ }^{5}$ when there is no evidence of peripheral leukemia. ${ }^{10}$ Granulocytic sarcoma can be a source of relapse of chronic myeloid leukemia as in our case. ${ }^{7}$ Relapses occur in about $4-5 \%$ cases of CML and AML and much lower in case of MDS. Urinary obstruction in granulocytic sarcoma of prostate in acute leukemia is reported,10,11 but not in granulocytic sarcoma of prostate in chronic myeloid leukemia as in our case. Primary granulocytic sarcoma of chronic myeloid leukemia in association with benign hyperplasia is not reported in literature and perhaps could be a nidus for relapse of leukemia and a stimulus for benign prostatic hyperplasia.

\section{REFERENCES:}

1. Burns A. Observations of surgical anatomy in Head and Neck; London Royce. 2003; 364.

2. King A. A case of chloroma.1853; Monthly J Med 17: 17.

3. Rappaport H, Tumors of the hematopoietic system, Atlas of Tumor Pathology, Section III, Fascicle 8.Washington DC: Armed Forces Institute of Pathology.1967; 241-7.

4. Byrd JC, Edenfield WJ, Shields DJ, etal. Extramedullary myeloid cell tumors in acute nonlymphocytic leukemia, a clinical review. J clin Oncol 1995; 13: 7: 1800-16.

5. Traweek ST, Arber DA, Rappaport H, et al. (October 1993). "Extramedullary myeloid cell tumors. An immunohistochemical and morphologic study of 28 cases". Am J Surg Pathol 1993; 17: 10: 1011-9.

6. Pui MH, Fletcher BD, Langston JW. Granulocytic sarcoma in childhood leukemia: imaging features. Radiology, 1994; 190: 698-702.

7. Guermazi. A, Feger. C, Rousselot. P, et al. Granulocytic Sarcoma (Chloroma) Imaging Findings in adults and Children. American_Journal_of_Roentgenology 2002; 178: 2: 319-25.

8. Freedy RM, Miller KD Jr. Granulocytic sarcoma (chloroma): sphenoidal sinus and paraspinal involvement as evaluated by CT and MR. AJNR 1991; 12: 259-262. 


\section{CASE REPORT}

9. Marcos HB, Semelka RC, Woosley JT. Abdominal granulocytic sarcomas: demonstration by MRI. Magn Reson Imaging 1997; 15: 873-876.

10. Joshi A, Patel A, Patel K, et al.myeloid sarcoma of prostate with urinary obstruction: an unusual presentation of acute myelogenous leukemia in a child. Indian journal of medical \&pediatric oncology 2005; 26: 2, 40-42.

11. Quein ET, Wallach B, Sandhaus L, et al. Primary extramedullary leukemia of the prostate: Case report and review of literature. Am J Hematol. 1996; 53, 4: 267-71.

12. Paydas S, Zorludemir S, Ergin M. Granulocytic sarcoma 32 cases and review of Literature. Leukemia \& Lymphoma, 2006; 47: 12: 2527-2541.

Fig. 1: photomicrograph showing glandular stromal hyperplasia with nodular Leukemic infiltration $\mathrm{H}$ \& E X 45.

Fig. 2: prostate tisuue showing nodular Leukemic infiltrate with surrounding smooth muscle hyperplasia H\&E X 100.

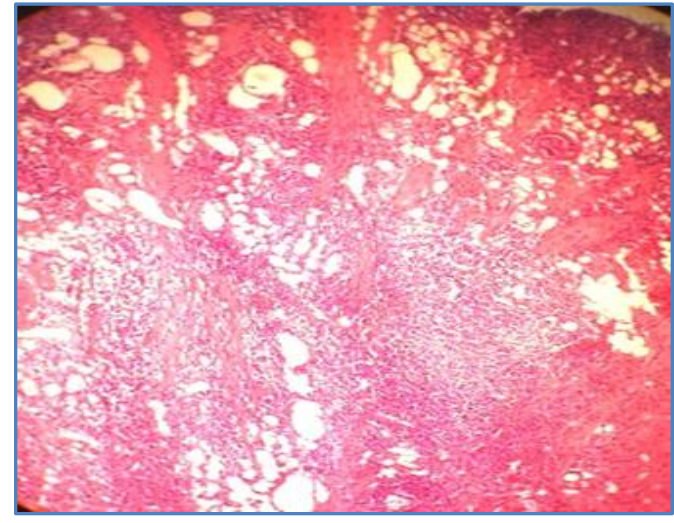

Fig. 1

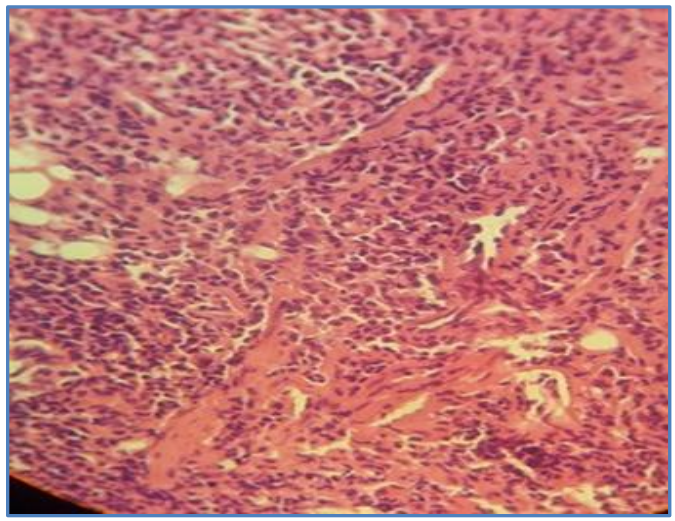

Fig. 2

Fig. 3: Prostate tisuue showing nodular Leukemic cell infiltrate showing polymorphism of Leukemic infiltrate H\&E X 400.

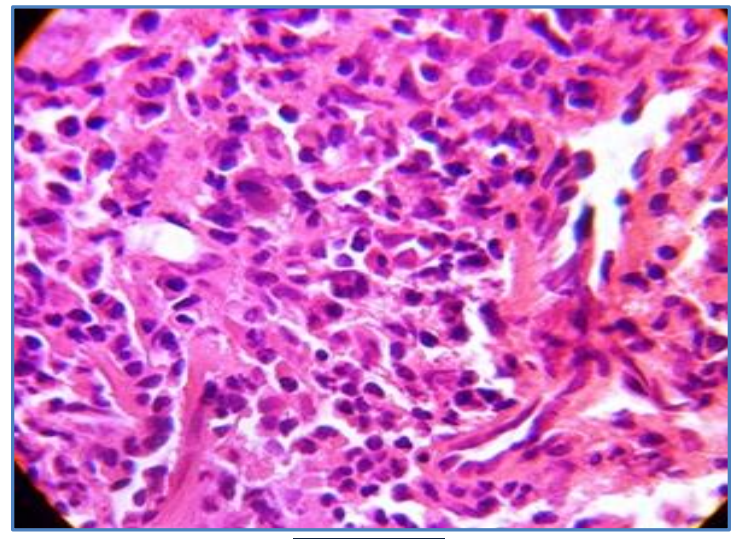

Fig. 3 


\section{CASE REPORT}

\section{AUTHORS:}

1. Anitha $S$.

2. Prasad K. R. K.

3. Sai Vittal

4. Ravi Kumar M.

\section{PARTICULARS OF CONTRIBUTORS:}

1. Assistant Professor, Department of Pathology, Mallareddy Medical College for Women, Suraram.

2. Professor, Department of Pathology, Mallareddy Medical College for Women, Suraram.

3. Assistant Professor, Department of Internal Medicine, Mallareddy Medical College for Women, Suraram.

FINANCIAL OR OTHER

COMPETING INTERESTS: None
4. Assistant Professor, Department of General surgery, Mallareddy Medical College for Women, Suraram.

\section{NAME ADDRESS EMAIL ID OF THE CORRESPONDING AUTHOR:}

Dr. Anitha S,

Assistant Professor, Department of Pathology, Mallareddy Medical College for Women, Suraram-500055, R. R. District,

Telangana.

E-mail: sunkara2310@gmail.com

Date of Submission: 28/07/2015. Date of Peer Review: 29/07/2015. Date of Acceptance: 13/08/2015. Date of Publishing: 20/08/2015. 